\title{
Preoperative assessments by trained nurses were equal in quality to assessments by preregistration house officers
}

\author{
Kinley H, Czoski-Murray C, George S, et al. Effectiveness of appropriately trained nurses in preoperative assessment: \\ randomised controlled equivalence/non-inferiority trial. BMJ 2002;325:1323-6.

\section{QUESTION: Are preoperative assessments by trained nurses equal in quality to those done by preregistration house officers?}

\section{Design}

Randomised (allocation concealed), unblinded, controlled equivalence/non-inferiority trial.

\section{Setting}

4 hospital sites in 3 UK National Health Service Trusts.

\section{Patients}

1907 patients who required assessment before general anaesthesia for general, vascular, urological, or breast surgery. 1874 patients (98\%) were included in the analysis (mean age $57 \mathrm{y}, 49 \%$ women).

\section{Intervention}

954 patients were allocated to preoperative assessment by a nurse who had completed master's level courses in advanced practice or equivalent. 953 patients were allocated to assessment by a preregistration house officer.

\section{Main outcome measures}

1 of 2 specialist registrars in anaesthesia examined each patient after the nurse or house officer and assessed their performance in each of history taking, physical examination, and test ordering as "correct," "overassessment," "underassessment not affecting perioperative management," and "underassessment possibly affecting perioperative management."

Source of funding:

National Coordinating Centre for Health Technology Assessment.

For correspondence: Professor J Primrose, University Surgery, University of

Southampton School of

Medicine, Southampton

General Hospital,

Southampton. UK.

j.n.primrose@soton.ac.uk

\section{Main results}

In 259 patients, preoperative assessment was judged as "underassessment possibly affecting perioperative management." The number of such assessments did not differ for nurses and house officers (table). House officers ordered almost twice as many unnecessary tests as nurses (table). Nursing assessments were judged to be no worse overall than house officer assessments (test for non-inferiority: upper 95\% CI of observed \% difference [1.1\%] was less than the defined clinically important difference of a $3.7 \%$ increase in underassessment) (table). A

Quality of preoperative assessments by nurses $v$ house officers

\begin{tabular}{lccll}
\hline Outcomes & Nurses & $\begin{array}{l}\text { House } \\
\text { officers }\end{array}$ & $\begin{array}{l}\text { Observed difference } \\
(95 \% \mathrm{Cl})\end{array}$ & $\begin{array}{l}\text { Clinically } \\
\text { important } \\
\text { difference* }\end{array}$ \\
\hline $\begin{array}{l}\text { Underassessment possibly } \\
\text { affecting perioperative } \\
\text { management }\end{array}$ & $12.8 \%$ & $14.9 \%$ & $-2.1 \%(-5.3$ to 1.1$)$ & $3.73 \%$ \\
\hline $\begin{array}{l}\text { Overassessment (tests } \\
\text { ordered) }\end{array}$ & $13.6 \%$ & $23.5 \%$ & $-9.9 \%(-13.4$ to -6.4$) \dagger$ & $5.9 \%$ \\
\hline
\end{tabular}

${ }^{*}$ Calculated as $(1.25 \times$ house officer \%) - house officer \%.

†Statistically significant. clinically important difference was defined as a $25 \%$ increase in the event rate for "underassessment possibly affecting perioperative management" in the nursing group compared with the house officer group.

\section{Conclusion}

Preoperative assessments by trained nurses were equal in quality to assessments by preregistration house officers.

\section{COMMENTARY}

Few large randomised control trials directly compare the practice of registered nurses (RNs) and physicians-intraining. The study by Kinley $e t$ al showed that appropriately trained and experienced nurses were at least as effective as preregistration house officers in conducting preoperative assessments. Importantly, such nurses also ordered fewer inappropriate tests.

However, applying the results of the study by Kinley et al beyond its UK setting may be difficult. For example, the findings may not be applicable in countries that have different training programmes or have preoperative assessments done by more senior physicians. History taking and physical examination are skills that develop with time and experience. It is unclear whether the 2 groups had similar experiences in the amount of time they had to learn or apply these skills. An important influence on the outcome could be the undergraduate and postgraduate preparation of the nursing staff. Additionally, the lack of blinding of the registrar assessors could be regarded as a potential limitation, although this is probably offset by the independent expert panel review whose judgements did not change the results.

A larger question is whether the performance level found in this study (ie, a 1 in 7 chance of failing to detect something that might make a difference in the management of a patient) is an acceptable standard. A study designed to examine the differences between registered physicians and appropriately trained RNs is needed.

The study by Kinley et al will be of interest to facilities with medical staff shortages and those that employ advanced practice nurses. Facilities considering a change in practice based on these results will need to ensure that nurses have access to appropriate education and training. If nurses are to practice independently, some mechanism would need to be implemented to ensure and maintain nursing competencies in the required skills. Furthermore, some consideration should be given to evaluating nurse satisfaction with the scope of this position if one is to ensure effective staff retention in these roles.

Heather Sherrard, RN, MHA, CHE Vice President, Clinical Services University of Ottawa Heart Institute Ottawa, Ontario, Canada 